\section{$7 \quad$ Abstract}

\title{
Environmental sustainability analysis of UK whole wheat bioethanol and CHP systems
}

\author{
Elias Martinez Hernandez ${ }^{1}$, Muhammad H. Ibrahim¹, Matthew Leach², Phillip \\ Sinclair $^{2}$, Grant M. Campbell ${ }^{1}$ and Jhuma Sadhukhan ${ }^{2 *}$ \\ ${ }^{1}$ School of Chemical Engineering and Analytical Science, University of Manchester, M13 9PL, UK \\ ${ }^{2}$ Centre for Environmental Strategy, University of Surrey, GU2 7XH, UK
}

The UK whole-wheat bioethanol and straw and DDGS based combined heat and power (CHP) generation systems were assessed for environmental sustainability using a range of impact categories or characterisations (IC): cumulative primary fossil energy (CPE), land use, life cycle global warming potential over 100 years $\left(\mathrm{GWP}_{100}\right)$, acidification potential $(\mathrm{AP})$, eutrophication potential (EP) and abiotic resources use (ARU). The European Union (EU) Renewable Energy Directive's target of greenhouse gas (GHG) emission saving of $60 \%$ in comparison to an equivalent fossil based system by 2020 seems to be very challenging for stand-alone wheat bioethanol system. However, the whole-wheat integrated system, wherein the CHP from the excess straw grown in the same season and from the same land is utilised in the wheat bioethanol plant, can be demonstrated for potential sustainability improvement, achieving 85\% emission reduction and 97\% CPE saving compared to reference fossil systems. The net bioenergy from this system and from 172370 ha of grade 3 land is $12.1 \mathrm{PJ}$ $\mathrm{y}^{-1}$ providing land to energy yield of $70 \mathrm{GJ} \mathrm{ha}^{-1} \mathrm{y}^{-1}$. The use of DDGS as an animal feed replacing soy meal incurs environmental emission credit, whilst its use in heat or CHP generation saves CPE. The hot spots in whole-system identified under each impact category are as follows: bioethanol plant and wheat cultivation for CPE (50\% and 48\%), as well as for 
ARU (46\% and 52\%). EP and $\mathrm{GWP}_{100}$ are distributed among wheat cultivation (49\% and $37 \%)$, CHP plant (26\% and 30\%) and bioethanol plant (25\%, and 33\%), respectively.

Keywords: bioethanol, biorefinery, polygeneration, CHP, sustainability, LCA

* Author/s to whom correspondence should be addressed:

E-mail: jhumasadhukhan@gmail.com, Ph: +44 1483686642, Fax: +44 1483686671.

\section{Introduction}

In 2008/9, UK surplus wheat (dry basis) was around $3900000 \mathrm{Mg}$ available for the production of bioethanol [1]. Alongside, $3500 \mathrm{~kg} \mathrm{ha}^{-1}$ of accompanying wheat straws (dry basis) were produced, $60 \%$ of which, after incorporating the rest into the soil for retaining the soil nutrients, could have been made available for the generation of combined heat and power (CHP) [2]. In the UK, there is around $5000000 \mathrm{Mg} \mathrm{y}^{-1}$ of straw available for bioenergy purposes, 54\% coming from wheat, after accounting for its other current uses [3]. Transport is the main energy consuming sector in the UK, accounting for a quarter of the UK domestic energy use and GHG emissions. 93\% of those emissions come from road vehicles [4]. In order to reduce emissions and energy imports, the target is to introduce $5.26 \%$ of renewable fuels into the transport fuel by 2013/14 [5]. To meet this bioethanol demand, a production capacity of 1 billion L will be required in the UK by the year indicated. The amount of excess wheat available in the UK could provide 1.62 billion $\mathrm{L} \mathrm{y}^{-1}$ of bioethanol (according to bioethanol process studies in [6]). The target fraction for electricity from renewable resources is set at $10 \%$ by 2010 and $30 \%$ by 2020 (2\% from small-scale generation) [7]. This implies that $48.2 \mathrm{PJ} \mathrm{y}^{-1}$ of electricity is required from biomass by 2010 [8]. The excess straw available in the $\mathrm{UK}$ (at $14.6 \mathrm{MJ} \mathrm{kg}^{-1}$ ) can supply $29.2 \mathrm{PJ} \mathrm{y}^{-1}$ of electricity.

The EU Renewable Energy Directive has imposed a constraint on biofuel systems that only those saving $60 \%$ GHG emissions in comparison to the fuel they replace will be eligible for consideration for the 2020 target of $10 \%$ renewable energy in transport [9]. Whilst achieving this target from the bioethanol production alone can be an important consideration, 
integrated energy systems have greater potential in improving overall sustainability. The utilisation of rape seed to produce a range of products, biodiesel from the oil, heat from straw, heat and gas from glycerol and rape cake as animal feed has been investigated to achieve $60 \%$ emission reduction target [10]. Their studies have demonstrated the sustainability of indigenous biofuels in Ireland in comparison to equivalent biofuel imports from other resources [10-12]. A comprehensive comparison amongst various potential renewable energy systems in the UK has been shown by a streamlined LCA approach [13]. An excellent overview of environmental impact analysis of the large scale deployment of dedicated bioenergy crops (e.g. short rotation coppice (SRC) willow and poplar, miscanthus) and biomass for biofuels (e.g. wheat, sugar beet, oilseed rape) in the UK has also been reported [14]. A range of $\mathrm{GWP}_{100}\left(\right.$ as $\mathrm{CO}_{2}$-eq) values between $41 \mathrm{~g} \mathrm{MJ}^{-1}$ and $80 \mathrm{~g} \mathrm{MJ}^{-1}$ from bioethanol plants using different feedstock (sugar cane, sugar beet, wheat, corn), with corresponding potential GHG reductions in a range of $10 \%-53 \%$ was shown [15]. With a similar approach, the life cycle assessment (LCA) of bioethanol and CHP production systems from wheat straw, considering additional aspects like crop residue removal and decrease in grain yields has also been presented [16]. The calculations showed that the use of crop residues in a biorefinery reduced GHG emissions by about $50 \%$ and fossil energy demand by more than $80 \%$. The effect of the processing scale and different allocation methods (economic, physical and by system expansion) have been analysed within the Sweden context [17]. The results showed that the differences between various scales are small and suggested system expansion as an appropriate allocation method. A GWP 100 (as $\mathrm{CO}_{2}$-eq) of $43.5 \mathrm{~g} \mathrm{MJ}^{-1}$ from a wheat-based large scale bioethanol facility based on economic allocation was presented.

The above studies mainly focus on the analysis of key contributing factors in LCA of bioenergy systems from different feedstock [10-18]. However, the trend is to make 
comparisons among them but give less attention to the improvement of environmental performance on a specific system from their current status as in the case of bioethanol plants. Additionally, the LCA of integrated energy systems in the UK is under-explored. It is also imperative to undertake such studies in the appropriate context and present the assumptions, results and validations in the most transparent and coherent way.

The current work explores, through the life cycle methodologies, the improvement in environmental sustainability from wheat bioethanol to the whole wheat bioethanol plants, in which the DDGS and the wheat straws are also used to generate CHP, thereby enhancing the renewable energy mix into the system. Building upon bioenergy system overviews presented in literature [10-29], a detailed evaluation of the UK wheat bioethanol and lignocellulosic CHP plants was performed in the context of environmental sustainability. The life cycle impact (LCI) methods were used with impact factors from individual substances extracted from various sources [19-29], amongst which the more relevant ones are presented in Table 1. For various energy carriers, e.g. natural gas, electricity, diesel, etc., the factors from [19] were used.

Table 1 Common substances and characterisation factors for impact categories used in this study (per kg).

\begin{tabular}{|l|c|c|c|}
\hline SUBSTANCE & $\begin{array}{c}\mathrm{GWP}_{100}\left(\mathrm{CO}_{2} \text {-eq }\right) \\
\mathrm{kg}[20]\end{array}$ & $\begin{array}{c}\mathrm{AP}\left(\mathrm{SO}_{2} \text {-eq }\right) \\
\mathrm{kg}[21]\end{array}$ & $\begin{array}{c}\mathrm{EP}\left(\mathrm{PO}_{4}{ }^{3-} \text { eq }\right) \\
\mathrm{kg}[21]\end{array}$ \\
\hline $\mathrm{CO}_{2}$ & 1 & & \\
\hline $\mathrm{CH}_{4}$ & 25 & & \\
\hline $\mathrm{N}_{2} \mathrm{O}$ & 298 & & \\
\hline $\mathrm{CO}$ & 1.9 & & 0.13 \\
\hline $\mathrm{NO}_{\mathrm{x}}\left(\right.$ not $\left.\mathrm{N}_{2} \mathrm{O}\right)$ & & 0.7 & \\
\hline $\mathrm{SO}_{\mathrm{x}}$ & & 1 & \\
\hline $\mathrm{H}_{2} \mathrm{SO}_{4}$ & & 0.65 & \\
\hline $\mathrm{NH}_{3}$ & & 1.88 & 0.33 \\
\hline $\mathrm{NO}_{3}{ }^{-}$ & & & 0.42 \\
\hline $\mathrm{PO}_{4}{ }^{3-}$ & & & 1 \\
\hline
\end{tabular}


The specific objectives of this study include:

1) Assess the environmental impact of the UK wheat bioethanol plant [6] as a stand-alone system as well as a whole wheat system integrated with wheat straw CHP plant [30] using cumulative primary (fossil) energy (CPE), land use, global warming potential in a horizon of 100 years $\left(\mathrm{GWP}_{100}\right)$, acidification potential $(\mathrm{AP})$, eutrophication potential $(\mathrm{EP})$ and abiotic resources use (ARU) as IC.

2) Establish the marginal benefits in terms of $\mathrm{GWP}_{100}$ and primary energy savings, compared to the fossil resources to be replaced, e.g. natural gas for heat and electricity and gasoline for bioethanol.

3) Study the relative LCI of DDGS as a commodity to the production of heat and CHP, compared to its usage as animal feed.

\section{System definition}

Fig. 1 depicts the following alternatives evaluated through life cycle methodologies:

1) Stand-alone bioethanol plant; wheat bioethanol and straw CHP to grid system.

2) DDGS as a source of heat for wheat bioethanol plant.

3) DDGS as a source of CHP for wheat bioethanol plant.

4) Straw based CHP plant supplying energy to bioethanol plant and DDGS as an animal feed. Additionally, alternative 5) is a combination of the cases in 2 and 4, wherein selling of DDGS is also considered.

The basis of the conversion plants is $12000000 \mathrm{Mg} \mathrm{y}^{-1}$ of wheat grain and the corresponding amount of excess straw available, $360000 \mathrm{Mg} \mathrm{y}^{-1}$ (after assuming retention of the straws cultivated in the soil of $40 \%$ to maintain the soil's nutritional value). The yields and energy contents of products are reported in Table 2. 


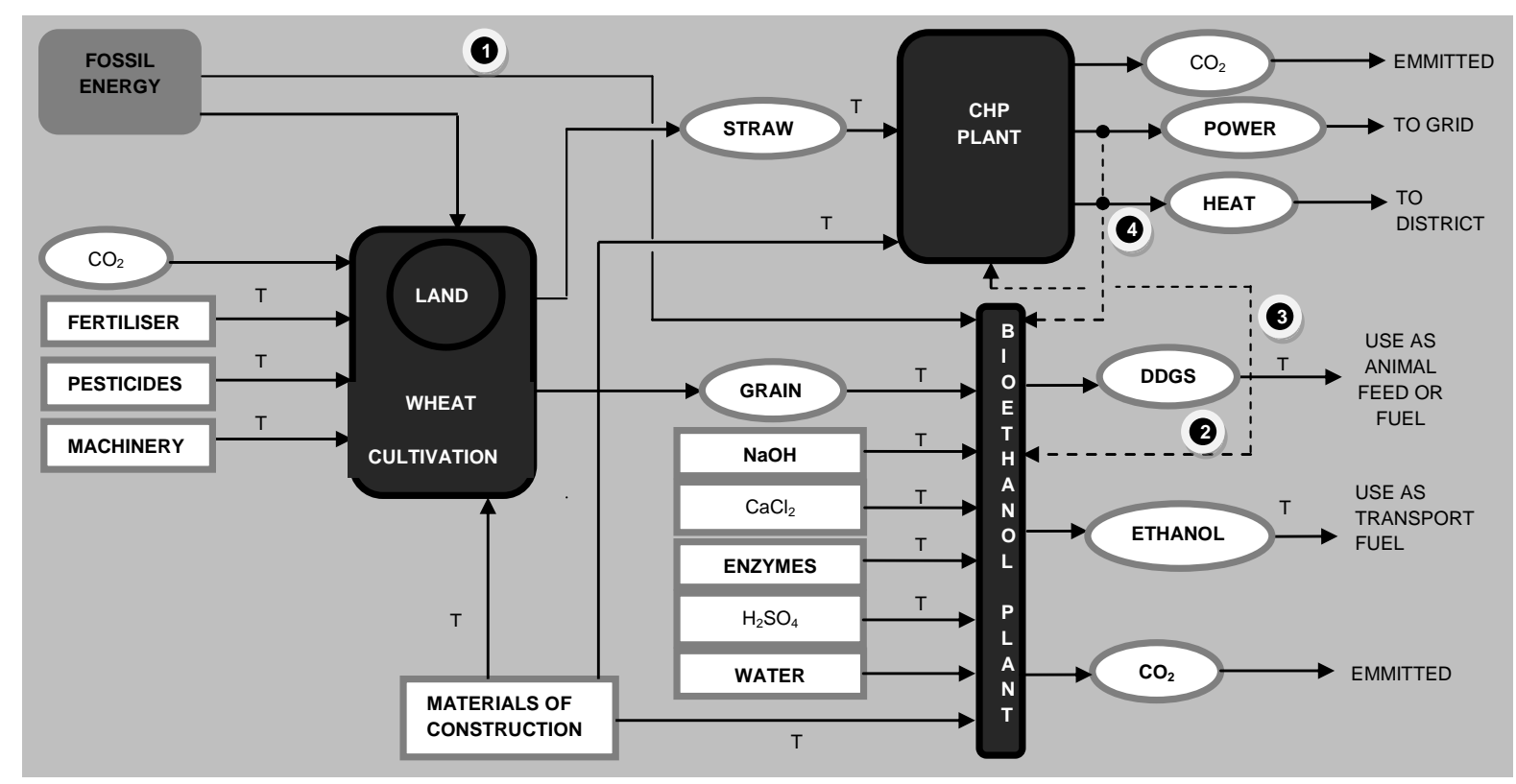

Fig. 1 The system evaluated. T: indicates transportation of materials. Dashed lines indicate the integration alternatives explored.

The boundaries of each subsystem include the farm and the plant gates for LCA. The allocation between the grain and the straw is by their economic values. For the conversion subsystems, three activities were separately evaluated and combined: LCI of materials of construction, plant operation, and transportation. The spreadsheet-based wheat bioethanol process model developed for technical analysis and economic feasibility [6] has been adopted. The results of simulation of biomass integrated gasification combined cycle (IGCC) plant for CHP generation in Aspen Plus were extracted for LCA [30]. The end use of ethanol is combustion as transportation fuel and of DDGS is in animal food processing in the base case, or as fuel for energy production in other cases. The electricity and heat generated from either the straw or from the DDGS were used within the bioethanol plant and added to adjacent grid connection and district heating system. Complementary energy such as electricity and natural gas is taken from the grid where necessary.

The LCI of individual co-production was allocated based on associated activities and operations. For shared facilities, this allocation was done by economic values. Different 
common functional units (unit mass of dry matter (DM) of product, unit energy, year and in the case of wheat cultivation, ha) were used for comparisons.

Table 2 Summary of yields (in dry matter basis) of wheat cultivation and bioethanol and

CHP generation plants.

\begin{tabular}{|l|l|l|l|l|}
\hline Subsystem & Product & Yield & Unit & $\begin{array}{l}\mathrm{LHV}^{\mathrm{a}} \\
\mathrm{MJ} \mathrm{kg}^{-1}\end{array}$ \\
\hline \multirow{3}{*}{ Wheat cultivation [19] } & Wheat & 6960 & $\mathrm{~kg} \mathrm{ha}^{-1}$ & 18.6 \\
\cline { 2 - 5 } & Straw & 3490 & $\mathrm{~kg} \mathrm{ha}^{-1}$ & 14.6 \\
\hline \multirow{2}{*}{ Bioethanol plant [6] } & Ethanol & 0.34 & $\mathrm{~kg} \mathrm{~kg}^{-1}$ (wheat basis) & $26.7[13]$ \\
\cline { 2 - 5 } & DDGS & 0.25 & $\mathrm{~kg} \mathrm{~kg}^{-1}$ (wheat basis) & 18.2 \\
\hline \multirow{3}{*}{ Straw CHP plant [30] } & Electricity & 1.06 & $\mathrm{kWh} \mathrm{kg}^{-1}$ (straw basis) & \\
\cline { 2 - 6 } & Heat & 0.567 & $\mathrm{kWh} \mathrm{kg}^{-1}$ (straw basis) & \\
\cline { 2 - 5 } & Efficiency & 40 & $\%$ & \\
\hline
\end{tabular}

a. LHV: lower heating value.

\section{Life cycle assessment}

\subsection{Wheat cultivation}

The LCI data of wheat cultivation in the UK (Fig. 2) were extracted from [19].

Various applications of nitrogen fertiliser are generally made followed by sprayings of

pesticides ( 2 doses assumed). The grain (with moisture content of $15 \%-18 \%$ ) once

harvested is dried to avoid deterioration during storage and then is transported to the grain

store. A mass fraction of the straws of about $40 \%$ are chopped and ploughed back to the soil

to retain and improve the nutrient balance, soil fertility and organic carbon content. The rest

is baled and used within the farm or is sold for other purposes [2]. The wheat yield of 6960

$\mathrm{kg} \mathrm{ha}^{-1}$ and the corresponding straw yield of $3500 \mathrm{~kg} \mathrm{ha}^{-1}$ were determined (in dry basis)

using $200 \mathrm{~kg} \mathrm{ha}^{-1}$ of nitrogen fertiliser. Urea mass fraction of $20 \%$ and the rest ammonium

photosynthesis by the wheat plant was used [24]. and fertilisers. $\mathrm{N}_{2} \mathrm{O}$ emissions from the nitrogen fertiliser and organic matter decomposition 
in soil produce impacts [15]. Direct field emissions from nitrogen fertiliser and organic matter decomposition in soil and indirect field emissions from nitrogen volatilisation, and deposition of nitrogen volatilised as $\mathrm{NH}_{3}+\mathrm{NO}_{\mathrm{x}}$, were determined based on the estimated

154 factors by IPCC, Tier 1 [22].

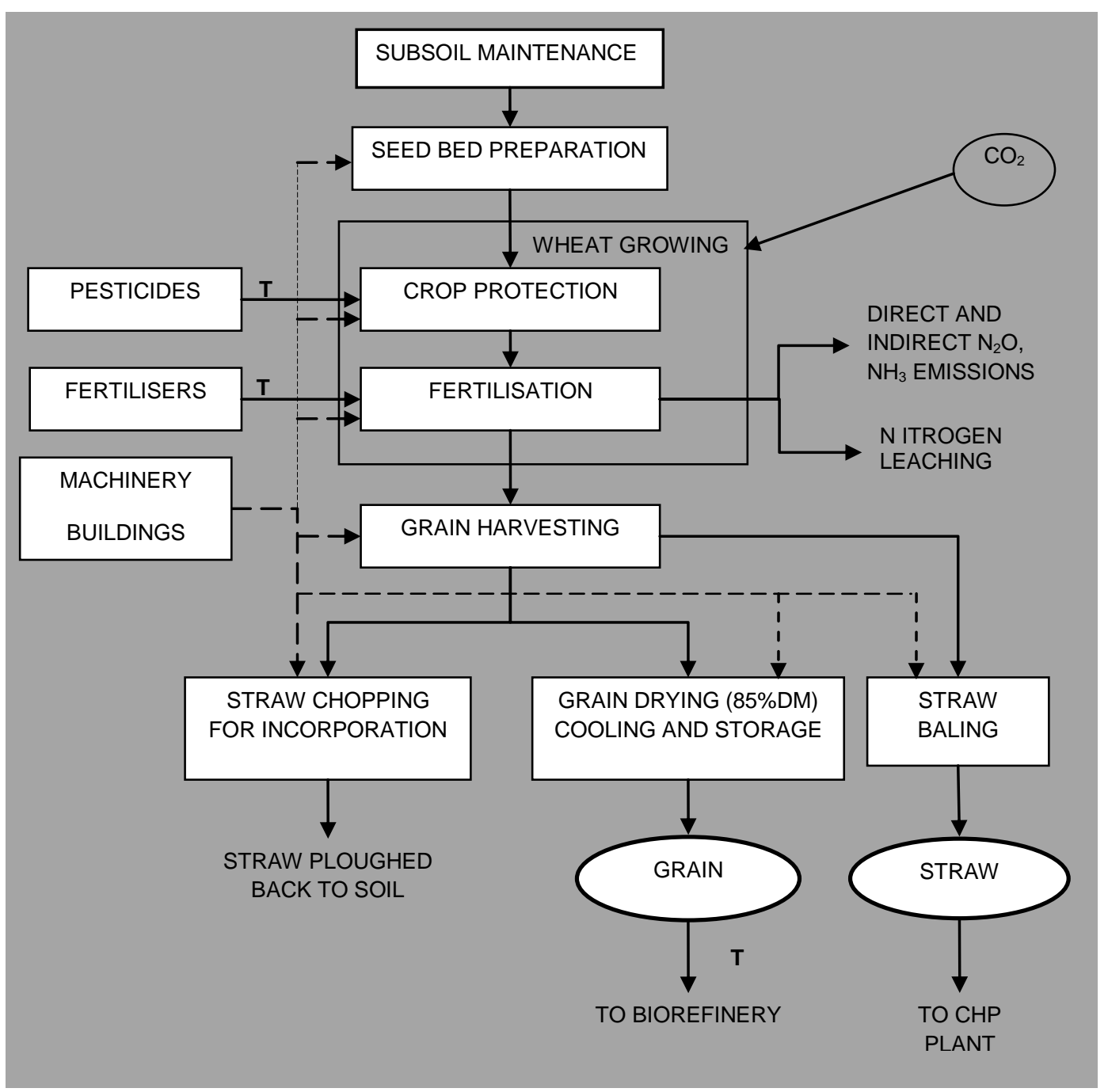

Fig. 2 The main activities in the UK cultivation system. Every activity implies machinery

operations with its inherent energy use and environmental impact for manufacturing, housing and transportation. Transportation is denoted by T. DM: dry matter.

The total CPE and allocation of impacts to grain and straw were predicted following the default relative economic value factor of straw to grain of 0.05 [19] and depending on $40 \%$ of straws incorporated in the soil in this study. The activities up to grain harvesting were 
common since the straw production (baling) occurs only after grain harvesting (Fig. 2). The

resulting allocation values in different functional units are given in Table 3.

Table 3 Allocation of CPE and environmental impacts from wheat cultivation.

\begin{tabular}{|c|c|c|c|c|c|c|}
\hline Product & $\begin{array}{c}\text { Functional } \\
\text { unit }\end{array}$ & $\begin{array}{c}\text { CPE } \\
\text { MJ }\end{array}$ & $\begin{array}{c}\mathbf{G W P}_{100} \\
\left(\mathrm{CO}_{2}-\mathbf{e q}\right) \\
\mathrm{kg}\end{array}$ & $\begin{array}{c}\mathrm{EP} \\
\left(\mathrm{PO}_{4}{ }^{3-} \text {-eq) }\right. \\
\mathrm{kg}\end{array}$ & $\begin{array}{c}\mathrm{AP} \\
\left(\mathrm{SO}_{2}-\mathrm{eq}\right) \\
\mathrm{kg}\end{array}$ & $\begin{array}{c}\text { ARU } \\
\text { (Sb-eq) } \\
\text { kg }\end{array}$ \\
\hline Grain & ha & 18335 & 3426 & 16.1 & 15.8 & 10.8 \\
\hline Straw & ha & 632 & 77 & 0.2 & 0.2 & 0.30 \\
\hline Total & ha & 18967 & 3503 & 16.3 & 16.0 & 11.1 \\
\hline Grain & $\mathrm{Mg}$ & 2634 & 492 & 2.3 & 2.3 & 1.5 \\
\hline Straw & $\mathrm{Mg}$ & 181 & 22 & 0.1 & 0.1 & 0.1 \\
\hline Grain & $\mathrm{y}$ & $3.16 \mathrm{PJ}$ & $591000 \mathrm{Mg}$ & $2770 \mathrm{Mg}$ & $2720 \mathrm{Mg}$ & $1850 \mathrm{Mg}$ \\
\hline Straw & $\mathrm{y}$ & $0.109 \mathrm{PJ}$ & $13300 \mathrm{Mg}$ & $41.7 \mathrm{Mg}$ & $42.5 \mathrm{Mg}$ & $52.6 \mathrm{Mg}$ \\
\hline Total & $\mathbf{y}$ & 3.27 PJ & $604000 \mathrm{Mg}$ & $2810 \mathrm{Mg}$ & $2760 \mathrm{Mg}$ & $1910 \mathrm{Mg}$ \\
\hline \multicolumn{2}{|l|}{ Land use } & $\begin{array}{c}\text { Grade } 2 \\
\text { Ha }\end{array}$ & $\begin{array}{c}\text { Grade } 3 a \\
\text { ha }\end{array}$ & $\begin{array}{c}\text { Grade 3b } \\
\text { ha }\end{array}$ & $\begin{array}{c}\text { Grade } 4 \\
\text { ha }\end{array}$ & \\
\hline Total & $\mathrm{y}$ & 151685 & 172370 & 186159 & 193054 & \\
\hline Grain & $\mathrm{Mg}$ & 0.13 & 0.14 & 0.16 & 0.16 & \\
\hline
\end{tabular}

The results are assimilated for a range of activities, Fertilisers and Pesticides (F\&P),

(FE) in Fig. 3. The CPE and GWP ${ }_{100}$ impacts from various wheat production activities are

compiled in Table 3. The output raw energy available in the form of grain and straw

(calculated from LHV in Table 2) gives a land productivity of $129.5 \mathrm{GJ} \mathrm{ha}^{-1}$ from an input

CPE of 18.967 GJ ha ${ }^{-1}$ (Table 3). This leads to an energy ratio, $E_{\text {ratio }}=$ output LHV / input

CPE, of 6.82 from the wheat cultivation system.

Fig. 3) due to $\mathrm{NO}_{3}{ }^{-}$leaching and $\mathrm{NH}_{3}$ emissions. Regarding acidification potential, it is dominated by $\mathrm{NH}_{3}$ emissions. 
production. Both are related to the nutrient balance in the soil which is still an issue to processing.
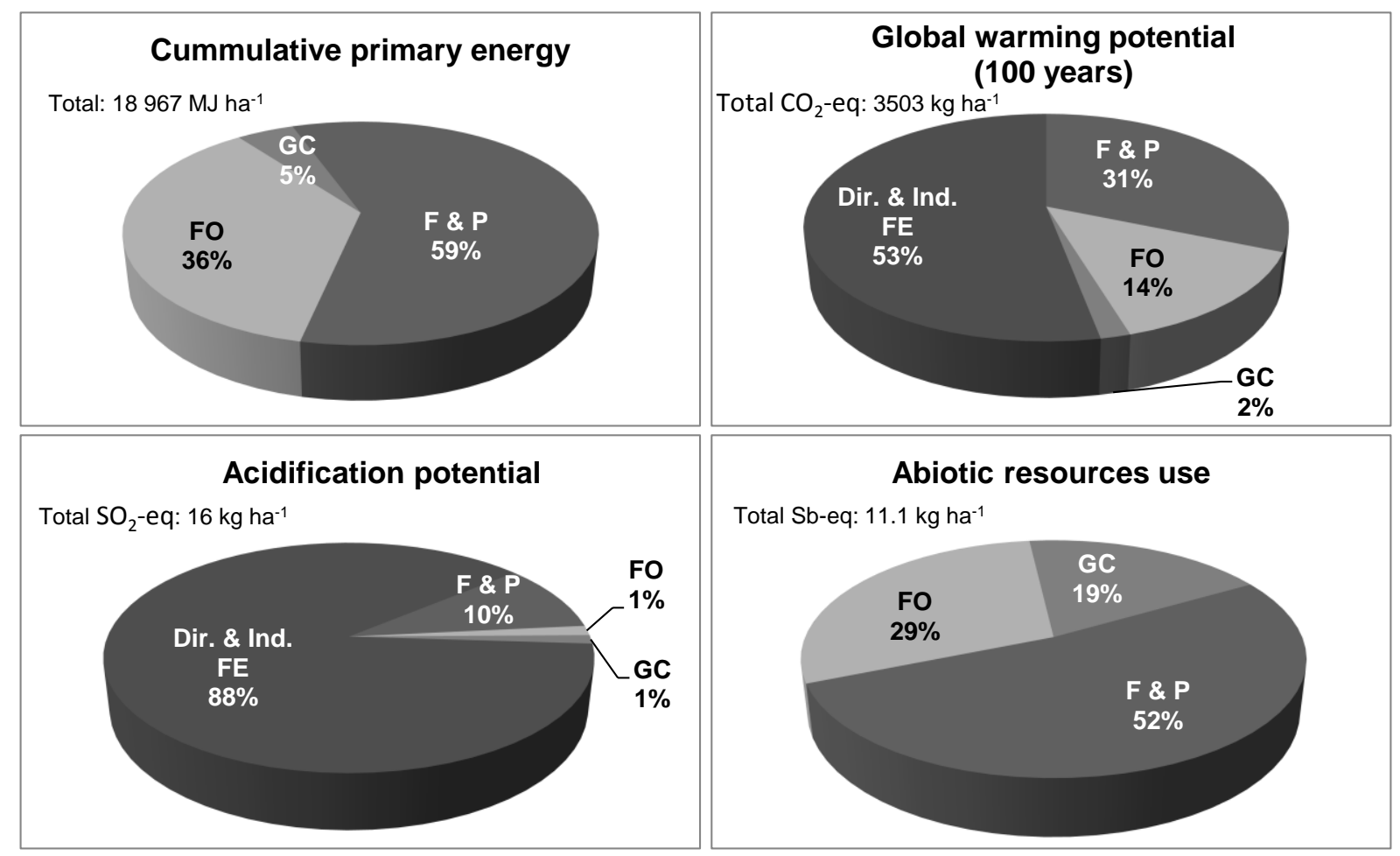

Fig. 3 Distribution of CPE and main environmental impact categories from wheat cultivation. FO: Field Operations, F\&P: Fetilisers and Pesticides, Dir. \& Ind. FE: Direct and Indirect Field Emissions, GC: Grain Conditioning.

\subsection{Wheat bioethanol system}

The wheat to bioethanol process model comprising hammer milling, liquefaction, saccharification, fermentation, centrifugation, ethanol recovery and drying as the main units [6] was used for the generation of mass and energy balance presented in Fig. 4. The simulation is based on the processing of the total wheat grain produced from cultivation into $404000 \mathrm{Mg} \mathrm{y}^{-1}$ of ethanol, $361000 \mathrm{Mg} \mathrm{y}^{-1}$ of $\mathrm{CO}_{2}$ (emitted to atmosphere), and $295000 \mathrm{Mg} \mathrm{y}^{-}$ ${ }^{1}$ of DDGS. The plant operates for 330 days a year and the plant life was assumed to be 10 
years. Water recovered from the distillation columns is recycled into the process. For the base case, natural gas is used to supply the heat required by the fermentation, distillation and drying.

The various substances consumed, $\alpha$-amylase, $\mathrm{CaCl}_{2}$ (liquefaction), glucoamylase, $\mathrm{H}_{2} \mathrm{SO}_{4}$ conc. (saccharification) and yeast (fermentation) in the bioethanol production are presented in Table 4. $\mathrm{NaOH}$ is also required; a detailed inventory of its production was included [27]. Yeast was assumed to have equivalent LCI as glucoamylase. Additional emissions were accounted for the transportation of the substances from their production gate to the bioethanol plant assuming a distance of $120 \mathrm{~km}$. Wheat is assumed to be transported from the farm gate to the bioethanol plant located within a radius of $25 \mathrm{~km}$ estimated from the total land use (grade 3a in Table 3). A mass fraction of 30\% of all materials transported by lorry and the rest by rail [19] was assumed to determine the energy requirements and environmental impact from transportation.

Table 4 Substances and environmental impacts data (per kg).

\begin{tabular}{|l|c|c|c|c|c|}
\hline \multicolumn{1}{|c|}{ Substance } & $\begin{array}{c}\mathrm{CPE} \\
\mathrm{MJ}\end{array}$ & $\begin{array}{c}\mathrm{GWP}_{100} \\
\left(\mathrm{CO}_{2} \text {-eq }\right) \\
\mathrm{kg}\end{array}$ & $\begin{array}{c}\mathrm{EP} \\
\left(\mathrm{PO}_{4}{ }^{3-} \text {-eq }\right) \\
\mathrm{kg}\end{array}$ & $\begin{array}{c}\mathrm{AP} \\
\left(\mathrm{SO}_{2} \text {-eq }\right) \\
\mathrm{kg}\end{array}$ & Ref. \\
\hline$\alpha-$ amylase & 15 & 1 & 0.0015 & 0.005 & {$[28]$} \\
\hline Glucoamylase & 90 & 7.7 & 0.0215 & 0.023 & {$[28]$} \\
\hline $\mathrm{CaCl}_{2}$ & 8.40 & & & & {$[29]$} \\
\hline $\mathrm{H}_{2} \mathrm{SO}_{4}$ Conc. & -3 & 0.004 & & 0.005 & {$[29]$} \\
\hline
\end{tabular}
mass fractions of $70 \%$ and $30 \%$, respectively. The steel requirement was determined from the preliminary sizing of the key equipment made up of tanks and columns, and other vessels according to [31 -33]. Residence time used in the calculations and amounts of steel are presented in Table 5. A detailed inventory for stainless steel grade 316 [25] was used to determine the environmental impact from the amounts in Table 5. At the end of the life of the 
plant the steel can be recycled, thus considered a credit within the inventory. The emissions

212 from concrete production were estimated from that of cement [26]. The LCI was increased by

$20 \%$ and $10 \%$ for buildings and general structural elements in the facility and for the

214 decommissioning of the plant at the end of life, respectively. A distance of $120 \mathrm{~km}$ was assumed for the transportation of materials of construction, as before.

Table 5 Main equipment and amount of steel required assuming cylindrical shapes.

\begin{tabular}{|l|c|c|c|}
\hline Unit & $\begin{array}{c}\mathrm{RT}^{\mathrm{a}}[31] \\
\mathrm{h}\end{array}$ & $\begin{array}{c}\text { Capacity } \\
\mathrm{m}^{3}\end{array}$ & $\begin{array}{c}\text { Steel }^{\mathrm{b}} \\
\mathrm{kg}\end{array}$ \\
\hline Liquefaction & 1 & 364 & $10779(1 \%)$ \\
\hline Saccharification & 5 & 2020 & $33810(4 \%)$ \\
\hline Fermentation (10 tanks) & 68 & 27475 & $420294(52 \%)$ \\
\hline Centrifugation & 1 & 1083 & $22312(3 \%)$ \\
\hline Ethanol recovery & 3 columns & 5188 & $123154(15 \%)$ \\
\hline Rotary dryer & 1 & 1083 & $22312(3 \%)$ \\
\hline Condensate tank & 6 & 14100 & $123479(15 \%)$ \\
\hline Ethanol tank & 24 & 4369 & $56541(7 \%)$ \\
\hline TOTAL & & & $\mathbf{8 1 2 6 8 2}$ \\
\hline
\end{tabular}

b. Numbers in brackets are mass fractions of the total amount.

Fig. 4 depicts the environmental impact and CPE flows for the cradle to the bioethanol plant gate subsystem including wheat cultivation, transportation and plant operation and construction. The construction stage represents only a small fraction (1\% or less) of the total environmental impact of the plant.

The impact from wheat grain production is the maximum, followed by bioethanol process operation, transportation and materials of construction in all the IC. The GHG emission from the process is caused from the use of energy and fermentation. The GWP $\mathrm{G}_{100}$ (as $\mathrm{CO}_{2}$-eq) from cradle to the bioethanol plant gate represented a value of $0.95 \mathrm{~kg} \mathrm{~kg}^{-1}$ for the UK wheat grain processed, or $6.78 \mathrm{Mg} \mathrm{ha}^{-1}$ (based on grade 3a in Table 3). 

production $(E)$ of $10.8 \mathrm{PJ} \mathrm{y}^{-1}$ through ethanol is obtained from $22.3 \mathrm{PJ} \mathrm{y}^{-1}$ of cumulative

231 primary energy. In terms of the land use, the energy conversion from wheat to bioethanol

232 translates to a land productivity of $62.7 \mathrm{GJ} \mathrm{ha}^{-1} \mathrm{y}^{-1}$ (based on land grade $3 \mathrm{a}$ in Table 3). The

233 ethanol distillation columns and rotary dryer are the most energy consuming processes within

234 the bioethanol plant, indicating points for potential improvement. Replacing natural gas-

235 based energy and electricity from the grid with renewable CHP using integrated systems can

236 further enhance the environmental sustainability of bioethanol production and usage,

237 discussed later.

\begin{tabular}{|c|c|c|c|c|c|c|c|c|c|c|c|c|c|c|}
\hline & Units of fl & lows & & & & Legend & & & & & & & Recycled & \\
\hline & Material & ${\operatorname{Mg~} y^{-1}}^{-1}$ & $A P$ & $M g y^{-1}$ & & $\overline{\text { SACCHA }}$ & ARIFC. & Sacchar & rification & Oper. & Plant & & Water & Ethanol \\
\hline & CPE & GJ $y^{-1}$ & EP & $\mathrm{Mg}^{-1}$ & & Cultiv. & & Wheat c & zultivation & & Operation & & 1891 & 404 \\
\hline & $\mathrm{GWP}_{100}$ & $M g y^{-1}$ & ARU & $\mathrm{kg} \mathrm{y}^{-1}$ & & Const. & & Plant co & nstruction & & & & & \\
\hline & & & & & & Transp. & & Transpo & ortation & & & & & \\
\hline & & & & & & & & & & & & & Ethanol & Recovery \\
\hline & $\alpha-a m$ & nylase & 0.98 & & 6.00 & $\mathrm{NaOH}$ & 1.32 & Gluco & amylase & & & & CPE & 1443519 \\
\hline & $\overline{\mathrm{CPE}}$ & 14760 & & & CPE & 120000 & & CPE & 118800 & & $\mathrm{CO}_{2}$ & 361 & $\mathrm{GWP}_{100}$ & 86880 \\
\hline & $\mathrm{GWP}_{100}$ & 0.98 & & & $\mathrm{GWP}_{100}$ & 7 & & $\mathrm{GWP}_{100}$ & 0.01 & & & & AP & 43 \\
\hline & AP & 2 & & & AP & 30 & & AP & 20 & & & & EP & 0 \\
\hline & EP & 1476 & & & EP & 0 & & EP & 28 & & & & ARU & 740738 \\
\hline & ARU & 6345 & & & ARU & 51583 & & ARU & 51067 & & & & & \\
\hline & & & & $\Downarrow$ & & & $\downarrow$ & & & & & & & \\
\hline & HAMER M & IILL & & LIQUEF & ACTION & & $\mathrm{SACCH}$ & ARIFC. & & FERME & ENTATION & & CENTRIF & UGATION \\
\hline Wheat & CPE & 110134 & & CPE & 627982 & & CPE & 8280 & & CPE & 44208 & & CPE & 92194 \\
\hline 1200 & $G_{W} P_{100}$ & 6354 & & $G W P_{100}$ & 37749 & & $G W P_{100}$ & 478 & & $G W P_{10}$ & 2551 & & $G W P_{100}$ & 5319 \\
\hline & & 26 & & AP & & & AP & & & AP & & & AP & 22 \\
\hline & EP & 0 & & EP & 0 & & EP & & & EP & 0.02 & & EP & 0.04 \\
\hline & ARU & 38048 & & ARU & 319104 & & ARU & 2861 & & ARU & 15272 & & ARU & 31850 \\
\hline & $\mathrm{CaCl}_{2}$ & 1.44 & & & & & & & & 0.23 & Yeast & & ROTARY & DRYER \\
\hline & CPE & 12096 & & & 2208 & & 2.58 & $\mathrm{H}_{2} \mathrm{SO}_{4}$ & & CPE & 20808 & & CPE & 794861 \\
\hline & $\mathrm{GWP}_{100}$ & 2 & & & Process & & CPE & -7742 & & $\mathrm{GWP}_{10}$ & 0.002 & & $\mathrm{GWP}_{100}$ & 47627 \\
\hline & AP & 2 & & & water & & $\mathrm{GWP}_{100}$ & 10 & & AP & 4 & & AP & 41 \\
\hline & EP & 0.007 & & & & & AP & 13 & & EP & 5 & & EP & 0 \\
\hline & ARU & 5200 & & & & & & & & ARU & 8944 & & ARU & 393590 \\
\hline Impact & & Unit & Cultiv. & Const. & Transp. & Oper. & Total & & Utilities & $\begin{array}{c}\text { CPE } \\
\text { PJ y }^{-1}\end{array}$ & & & & \\
\hline$\overline{\mathrm{CPE}}$ & & $\mathrm{PJ} \mathrm{y}^{-1}$ & 3.16 & 0.01 & 0.02 & 3.40 & 6.60 & & Electricity & 0.39 & & & Waste & DDGS \\
\hline $\mathrm{GWP}_{100}$ & $\mathrm{CO}_{2}$-eq & $G g y^{-1}$ & 591 & 3 & 1 & 548 & 1143 & & Steam & 2.03 & & & 470 & 295 \\
\hline AP & $\mathrm{SO}_{2}$-eq & ${\operatorname{Mg~} y^{-1}}^{-1}$ & 2722 & 11 & 4.37 & 238 & 2976 & & $N G$ & 0.70 & & & & \\
\hline EP & $\mathrm{PO}_{4}^{3-}-\mathrm{eq}$ & $\operatorname{Mg~}^{-1}$ & 2772 & 0.51 & 0.52 & 1510 & 4283 & & Total & 3.12 & & & & \\
\hline ARU & Sb-eq & ${\operatorname{Mg~} y^{-1}}^{-1}$ & 1855 & 6 & 59 & 1665 & 3584 & & & & & & & \\
\hline
\end{tabular}


Fig. 4 Material and energy balances and environmental impacts associated with every stream and unit operation in the wheat bioethanol plant.

The economic values assigned in the study [6] have been taken as a basis for the allocation of LCI to ethanol and DDGS. The total environmental impact under each category for each product was determined by the allocation factor of the product $(A F)$ multiplied by the total environmental impact from common unit operations (CEI), plus the environmental impact from the unit operations used in the final recovery of that particular product (REI); i.e.: $A F \times C E I+R E I$. The allocation factor was calculated from the ratio of the value flow of the product (mass flow multiplied by economic value) divided by the sum of value flow of all products. This results in the factors of 0.962 and 0.038 for ethanol and DDGS, respectively. The LCI allocation to bioethanol and DDGS by economic values is presented in Table 6.

Table 6 LCI allocation to ethanol and DDGS by economic value (from cradle to the plant gate).

\begin{tabular}{|l|c|c|c|c|c|c|}
\hline Product & $\begin{array}{c}\text { Functional } \\
\text { unit }\end{array}$ & $\mathrm{CPE}$ & $\begin{array}{c}\mathrm{GWP}_{100} \\
\left(\mathrm{CO}_{2} \text {-eq }\right)\end{array}$ & $\begin{array}{c}\mathrm{AP} \\
\left(\mathrm{SO}_{2} \text {-eq }\right)\end{array}$ & $\begin{array}{c}\mathrm{EP} \\
\left(\mathrm{PO}_{4}{ }^{3-} \text {-eq }\right)\end{array}$ & $\begin{array}{c}\mathrm{ARU} \\
(\mathrm{Sb}-\mathrm{eq})\end{array}$ \\
\hline & & $\mathrm{PJ}$ & $\mathrm{Mg}$ & $\mathrm{Mg}$ & $\mathrm{Mg}$ & $\mathrm{Mg}$ \\
\hline Ethanol & $\mathrm{y}$ & 5.64 & 1057711 & 2826 & 4122 & 3098 \\
\hline DDGS & $\mathrm{y}$ & 0.96 & 85598 & 150 & 161 & 486 \\
\hline Total & $\mathbf{y}$ & $\mathbf{6 . 6 0}$ & $\mathbf{1 1 4 3 3 0 9}$ & $\mathbf{2 9 7 6}$ & $\mathbf{4 2 8 3}$ & $\mathbf{3 5 8 4}$ \\
\hline Ethanol & $\mathrm{Mg}$ & 0.00001394 & 2.62 & 0.01 & 0.01 & 0.0077 \\
\hline DDGS & $\mathrm{Mg}$ & 0.00000325 & 0.29 & 0.001 & 0.001 & 0.0016 \\
\hline
\end{tabular}

Table 7 presents cradle-to-grave $\mathrm{GWP}_{100}$ of wheat bioethanol production, including combustion, $\mathrm{CO}_{2}$ binding and product transportation. By considering the impact allocation to ethanol and DDGS by their economic values, the reduction in $\mathrm{GWP}_{100}$ impact of $39 \%$ is obtained in comparison to gasoline system. From the corresponding CPE (13.94 GJ Mg-1) and the energy produced from ethanol (Table 2), the energy ratio for bioethanol production is $E_{\text {ratio }}=1.92$. This ratio reported for the production of gasoline is 0.84 [14]. Thus, energy saving of $56 \%$ can be estimated. On the other hand, considering that $1 \mathrm{~kg}$ of DDGS can 
replace $0.8 \mathrm{~kg}$ of soy meal for animal feed [34] and the corresponding $\mathrm{GWP}_{100}$ of $0.726 \mathrm{~kg}$ $\mathrm{kg}^{-1}$ soy meal [35], 72\% of GHG emissions can be avoided by the replacement of soy meal in animal feed. A potential energy saving of $21 \%$ was estimated from the use of DDGS as animal feed. determined (51.6 $\mathrm{g} \mathrm{MJ}^{-1}$ ) fits within the range of $\left(40.8\right.$ - 79.6) $\mathrm{g} \mathrm{MJ}^{-1}$ given in [15] with potential $\mathrm{GWP}_{100}$ reduction by $10 \%-53 \%$. The resulting value is also comparable with 43.5 $\mathrm{g} \mathrm{MJ}^{-1}$ from bioethanol production in [17] and $44 \mathrm{~g} \mathrm{MJ}^{-1}$ reported in [14], based on similar system definition and economic allocation.

Table 7 Results of $\mathrm{GWP}_{100}\left(\mathrm{CO}_{2}\right.$-eq) and corresponding savings from the use of bioethanol as transport fuel and DDGS as animal feed, respectively.

\begin{tabular}{|c|c|c|c|}
\hline & Unit & Ethanol & DDGS \\
\hline $\begin{array}{ll}\text { Allocation } & \text { from } \\
\text { production } & \end{array}$ & \multirow{6}{*}{$\mathrm{kg} \mathrm{kg}^{-1}$} & 2.62 & 0.29 \\
\hline Ethanol combustion & & 1.91 & - \\
\hline Transportation & & 0.01 & 0.001 \\
\hline Total GWP 100 & & 4.5 & 0.29 \\
\hline $\mathrm{CO}_{2}$ binding by wheat & & -3.16 & -0.12 \\
\hline \multirow{2}{*}{ Net $\mathbf{G W P}_{100}$} & & 1.38 & 0.17 \\
\hline & $\mathrm{g} \mathrm{MJ}^{-1}$ & 51.6 & - \\
\hline Energy produced & \multirow{2}{*}{$\mathrm{MJ} \mathrm{kg}^{-1}$} & 26.72 & - \\
\hline Total CPE & & 13.94 & 3.25 \\
\hline $\mathbf{E}_{\text {ratio }}$ & - & 1.92 & - \\
\hline Reference values & - & gasoline & soy meal \\
\hline \multirow[t]{2}{*}{$\mathrm{GWP}_{100}$} & $\mathrm{~g} \mathrm{MJ}^{-1}$ & $84.6[14]$ & - \\
\hline & $\mathrm{kg} \mathrm{kg}^{-1}$ & - & $0.726[35]$ \\
\hline$E_{\text {ratio }}$ & $\mathrm{MJ} \mathrm{MJ}^{-1}$ & $0.84[14]$ & - \\
\hline $\mathrm{CPE}$ & $\mathrm{MJ} \mathrm{kg}^{-1}$ & - & $4.13[34]$ \\
\hline GWP $_{100}$ reduction & $\%$ & 39 & 72 \\
\hline CPE savings & $\%$ & 56 & 21 \\
\hline
\end{tabular}

\subsubsection{Sensitivity analysis}

Sensitivity analysis was carried out by variation of the percentage of renewable

274 electricity in the electricity mix, percentage of renewable fuel in transportation fuels and 
nitrogen fertilisation rates. The impact sources affected by these parameters are: transportation, field operation and drying. The biogenic carbon capture is not affected by these parameters and therefore $\mathrm{CO}_{2}$ binding and carbon emissions from end use of products are not changed. The initial UK electricity mix is $43.3 \%$ from natural gas, $32.9 \%$ from coal, $2.6 \%$ from fuel oil, $18.2 \%$ from nuclear energy and 3\% from renewable energy [19]. It was assumed that the biofuels replace an equivalent amount of fossil fuels and that the use of biofuel results in at least $50 \%$ reduction in $\mathrm{CPE}$ and $\mathrm{GWP}_{100}$ with respect to fossil fuels. The results of sensitivity analysis are shown as follows.

- $10 \%$ increase in renewable electricity in the electricity mix increases CPE by $0.02 \mathrm{PJ} \mathrm{y}^{-1}$ and reduces GWP ${ }_{100}$ by $1144 \mathrm{Mg} \mathrm{y}^{-1}$, EP by $0.005 \mathrm{Mg} \mathrm{y}^{-1}$, AP by $2.07 \mathrm{Mg} \mathrm{y}^{-1}$ and ARU by $17.7 \mathrm{Mg} \mathrm{y}^{-1}$.

- $10 \%$ biofuel in transportation fuels increases CPE by $0.07 \mathrm{PJ} \mathrm{y}^{-1}$ and reduces $\mathrm{GWP}_{100}$ by $3382 \mathrm{Mg} \mathrm{y}^{-1}$, EP by $0.10 \mathrm{Mg} \mathrm{y}^{-1}$, AP by $11.2 \mathrm{Mg} \mathrm{y}^{-1}$ and ARU by $5.86 \mathrm{Mg} \mathrm{y}^{-1}$.

- $10 \%$ reduction in nitrogen fertilisation rates increases CPE by $0.14 \mathrm{PJ} \mathrm{y}^{-1}$ and reduces $\mathrm{GWP}_{100}$ by $33351 \mathrm{Mg} \mathrm{y}^{-1}$, EP by $142 \mathrm{Mg} \mathrm{y}^{-1}$, AP by $346 \mathrm{Mg} \mathrm{y}^{-1}$ and ARU by $0.08 \mathrm{Mg} \mathrm{y}^{-1}$. Major changes came from the variation in nitrogen fertilisation rates. The estimated field emissions using IPCC guidelines are another source of uncertainty.

\subsection{Wheat bioethanol and straw CHP to grid system}

The biomass IGCC-based CHP system has been techno-economically proven to be competitive and environmentally superior to equivalent fossil-based (e.g. natural gas-based) CHP systems [30] and their implementation seems to be a reality [36]. The LCA of a process simulated in Aspen Plus by Sadhukhan et al. for the processing of $5.44 \mathrm{Mg} \mathrm{d}^{-1}$ straw (with moisture and ash mass fractions of $8.5 \%$ and $8.61 \%$, respectively, and LHV of $14.6 \mathrm{MJ} \mathrm{kg}^{-1}$ ) 
into the production of $241 \mathrm{~kW}$ of electricity and $129 \mathrm{~kW}$ of waste heat, was undertaken [30].

The scaled up LCA results in terms of CPE and $\mathrm{GWP}_{100}$ corresponding to $361000 \mathrm{Mg} \mathrm{y}^{-1}$ of straw processing into $1.38 \mathrm{PJ} \mathrm{y}^{-1}$ of electricity and $0.737 \mathrm{PJ} \mathrm{y}^{-1}$ of heat generation, and thereby whole system LCI results under all five IC are presented for the base case (alternative 1 in Fig. 1).

The $\mathrm{GWP}_{100}$ from the straw-based CHP plant is mainly from the operation (98\%) and the rest from the straw production and transportation and the plant construction. This impact mainly results from the emissions of the exhaust gas from the combustion of the syngas from straw gasification, made up of $\mathrm{CO}_{2}$ (molar fraction of $25 \%$ ), nitrogen (molar fraction of 62\%) and steam (molar fraction of 13\%) in the cases under consideration.

However, by considering $\mathrm{CO}_{2}$ fixation by straw (Carbon mass content of $36.6 \%$ ) there is a credit of $1.34 \mathrm{Mg} \mathrm{Mg}^{-1}$. Then, the net $\mathrm{GWP}_{100}$ (as $\mathrm{CO}_{2}$-eq) is reduced to $18 \mathrm{~g} \mathrm{kWh}^{-1}$. Thus, around 94\% reduction in GHG emissions can be achieved by the CHP generation from wheat straw with respect to equivalent production of CHP from natural gas [19]. Alternative to gasification is the combustion of straw to produce heat and/or electricity. The electricity-only system has been analysed with the plant gate as system boundary and taking into account the $\mathrm{CO}_{2}$ balance between that released by the processing and combustion and that fixed by the wheat plant [13]. Another conversion alternative is the wheat straw-based bioethanol and acetic acid system with lignin supplying CHP. However, wheat straw can be interchangeably used between CHP and bioethanol production, without any difference in environmental impacts.

Unlike the bioethanol plant, the construction stage in wheat straw CHP system becomes important in the case of CPE (28\%) and AP (25\%), respectively. Transportation also has impact towards ARU (35\%). For the other IC, the wheat straw cultivation incurs the 
maximum impacts, contributing by $66 \%$ to $\mathrm{CPE}, 68 \%$ to AP and $65 \%$ to ARU, respectively. Plant operation contributes the most to EP (98\%).

Table 8 compiles the results of bioenergy production from the base case system (alternative 1), wheat bioethanol and DDGS as animal feed; and straw-based CHP to grid. The following analysis is done for the system as a whole without any allocation of impacts. The net bioenergy produced is $12.9 \mathrm{PJ} \mathrm{y}^{-1}, 84 \%$ of which in the form of ethanol and the rest in the form of CHP. Therefore, the bioenergy harvested from the land cultivated after conversion is $74.9 \mathrm{GJ} \mathrm{ha}^{-1} \mathrm{y}^{-1}$. The $E_{\text {ratio }}$ obtained is 1.91 . The CPE requirements by the whole wheat cultivation, bioethanol plant operation and transportation and construction of the wheat bioethanol and CHP system are 3.27 $\mathrm{PJ} \mathrm{y}^{-1}$ (Table 3), $3.40 \mathrm{PJ} \mathrm{y}^{-1}$ (Fig. 4), $0.067 \mathrm{PJ} \mathrm{y}^{-1}$ and $0.041 \mathrm{PJ}^{-1}$, respectively. The CPE to produce the equivalent amount of energy and soy meal corresponds to $12.9 \mathrm{PJ} \mathrm{y}^{-1}$ from gasoline ( $E_{\text {ratio }} 0.84$ [14].), $1.1 \mathrm{PJ} \mathrm{y}^{-1}$ from heat generation from natural gas boiler $\left(E_{\text {ratio }}=0.7\right.$, assumed $), 4.4 \mathrm{PJ} \mathrm{y}^{-1}$ from electricity mix ( $3 \%$ of renewable mix in the current $\mathrm{UK}$ context), and $0.97 \mathrm{PJ}^{-1}$ from soy meal production (Table 7 and Table 8). This gives a total CPE of $19.37 \mathrm{PJ}^{-1}$ with an overall $E_{\text {ratio }}=0.66$. Therefore, about 65\% energy savings can be achieved from the whole bioenergy system.

Table 8 Annual products and bioenergy generated from the overall system (alternative 1).

\begin{tabular}{|l|l|l|l|l|}
\hline Subsystem & $\begin{array}{l}\text { Feedstock/ } \\
\text { Product }\end{array}$ & $\begin{array}{l}\text { Flow rate } \\
\text { Gg }\end{array}$ & $\begin{array}{l}\text { Bioenergy } \\
\text { PJ }\end{array}$ & $\begin{array}{l}\text { Soy meal } \\
\text { equivalent } \\
\text { Gg }\end{array}$ \\
\hline Cultivation & Wheat grain & 1200 & 22.3 & - \\
\hline Bioethanol Plant & Ethanol & 404 & 10.8 & - \\
\cline { 2 - 5 } & DDGS & 295 & - & 236 \\
\hline Cultivation & Wheat straw & 361 & 5.27 & - \\
\hline Straw CHP Plant & Electricity & - & 1.38 & - \\
\cline { 2 - 5 } & Heat & - & 0.737 & - \\
\hline $\begin{array}{l}\text { Total bioenergy equivalent to gasoline and } \\
\text { fossil CHP Systems }\end{array}$ & 12.9 & - \\
\hline
\end{tabular}


In the cradle to product utilisation (ethanol combustion) analysis of the whole base

case (wheat bioethanol and straw CHP to grid) system, the total $\mathrm{GWP}_{100}\left(\right.$ as $\mathrm{CO}_{2}$-eq) is

calculated as the sum of that from the whole wheat cultivation (Table 3), wheat bioethanol net $\mathrm{GWP}_{100}$, the total $\mathrm{CO}_{2}$ binding by the whole wheat plant is credited $\left(1810000 \mathrm{Mg} \mathrm{y}^{-1}\right)$.

Fig. 5 shows a systems diagram that represents the $\mathrm{GWP}_{100}$ flows from the different sources throughout the system life cycle per unit of total bioenergy produced (Table 8). This results in $57 \%$ reduction in $\mathrm{GWP}_{100}$ from stand-alone wheat bioethanol and straw CHP systems compared to gasoline production and combustion system [14], natural gas based heat generation system at 70\% thermal efficiency [19] and soy meal production system [35] together.

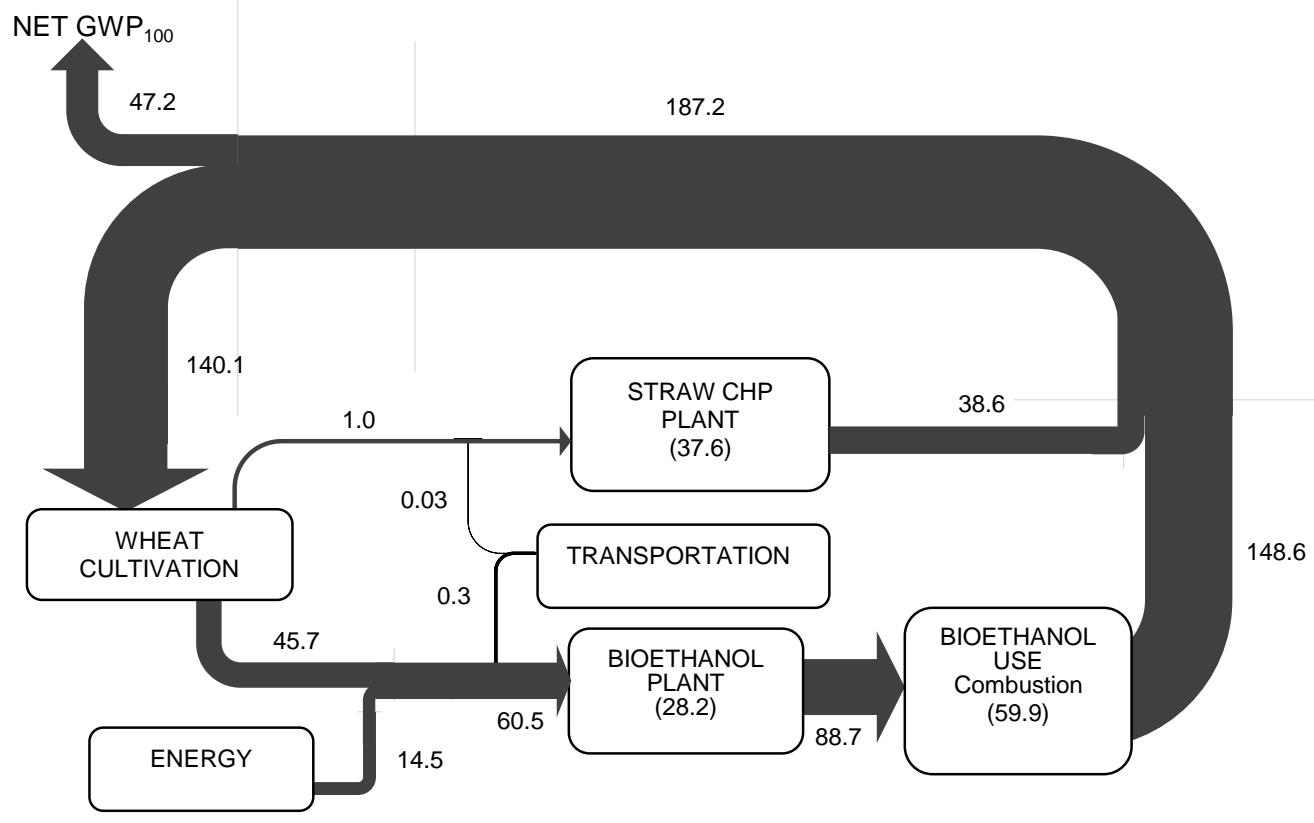


354 Fig. 5 Life cycle $\mathrm{GWP}_{100}\left(\mathrm{CO}_{2}\right.$-eq), in $\mathrm{g} \mathrm{MJ}^{-1}$, of the production of bioenergy (as ethanol, 355 heat and electricity) and DDGS in a whole wheat-based system. Values for CHP and 356 bioethanol plant include $\mathrm{GWP}_{100}$ from other raw materials, process emissions and 357 construction. subsystems included in the wheat bioethanol and straw CHP to grid system: whole wheat cultivation, wheat bioethanol plant operation, straw CHP plant operation, transportation and construction. The hot spots in the system are wheat cultivation and bioethanol plant for CPE (48\% and 50\% respectively), as well as for ARU (52\% and $46 \%$ respectively). EP and $\mathrm{GWP}_{100}$ are distributed among the three subsystems: wheat cultivation (47\% and $37 \%$ respectively), plant (27\% and 30\% respectively) and bioethanol plant (26\%, and 33\% respectively). Wheat cultivation $(91 \%)$ and bioethanol plant $(8 \%)$ dominate the contribution to AP.

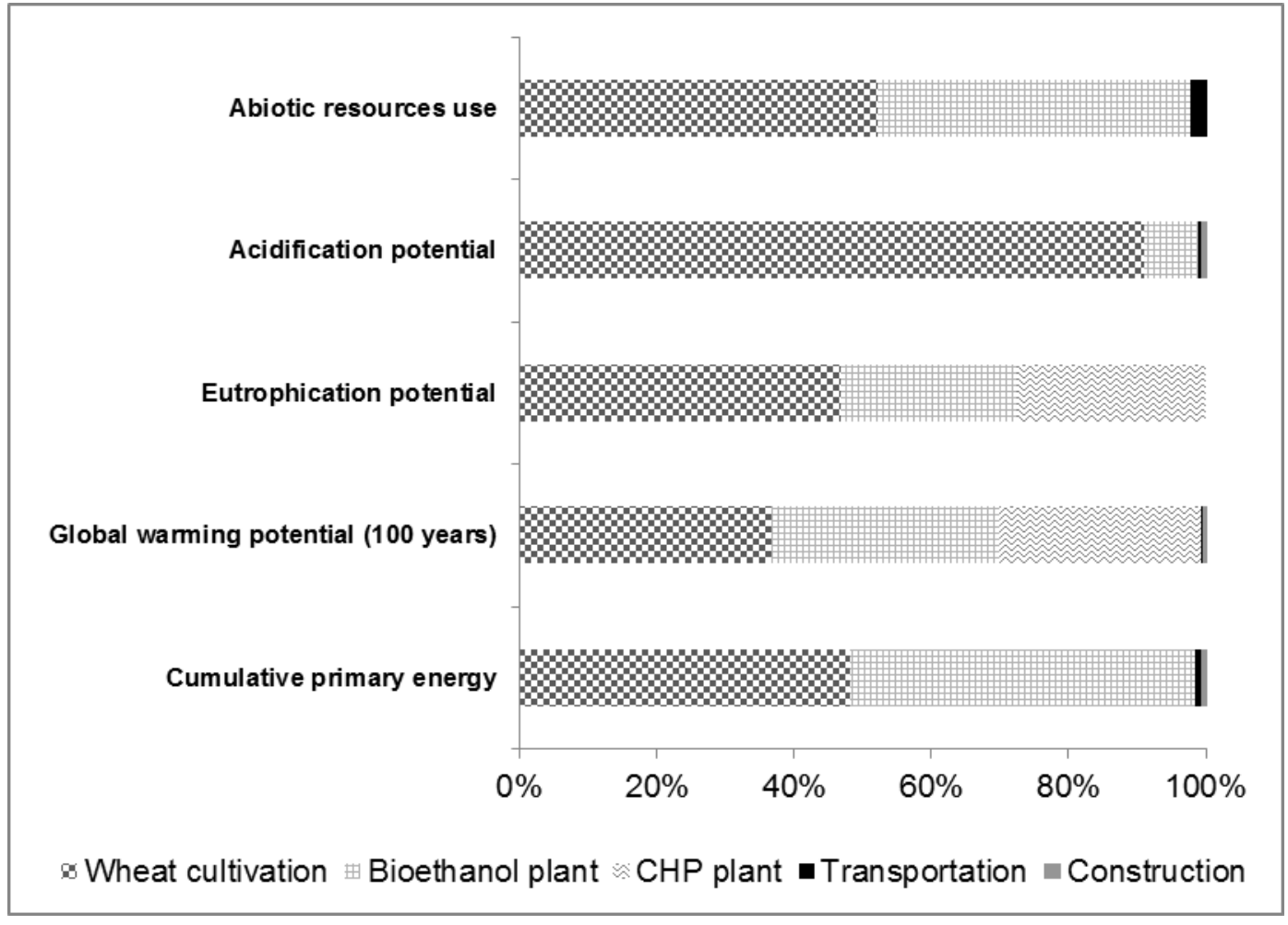

Fig. 6 Environmental impact of wheat bioethanol and straw CHP to grid system. 
Results presented here are comparable with those reported in literature for similar systems. The $\mathrm{GWP}_{100}$ (as $\mathrm{CO}_{2}$-eq) value allocated to electricity $\left(0.541 \mathrm{~kg} \mathrm{kWh}^{-1}\right.$, without $\mathrm{CO}_{2}$ balance consideration) from the CHP plant are comparable to those obtained from electricity generation from gasification of short rotation coppice willow chips of $0.482 \mathrm{~kg}$ $\mathrm{kWh}^{-1}$ for $\mathrm{GWP}_{100}$ with energy ratio of 19.3 [18]. The results of LCA of bioethanol and CHP production systems from wheat straw showed that the use of crop residues in a biorefinery reduces the GHG emissions by about $50 \%$ and fossil energy demand by more than $80 \%$ [16].

\section{Integrated system GWP 100 and CPE saving analyses}

The effect of the integration of the various bioenergy systems (straw- or DDGS-based CHP plant, heat production from DDGS and bioethanol plant) on the $\mathrm{GWP}_{100}$ reduction and CPE saving from the production and usage of bioethanol in reference to gasoline was analysed. The calculation of the combined net $\mathrm{GWP}_{100}$ and $\mathrm{CPE}$ was carried out following the substitution method taking the credits from the equivalent fossil-based energy and soy meal replacement by DDGS. The comparative reference systems for heat and electricity from straw are natural gas boiler for the generation of heat and grid electricity (UK electricity mix), respectively. Table 9 summarises the results of $\mathrm{GWP}_{100}, \mathrm{CPE}$, bioenergy production and the corresponding savings for each case. Additionally, an integrated system (5) wherein a part of DDGS-based heat and straw-based CHP are used in the wheat bioethanol plant is considered. from the natural gas boiler and electricity from grid (1), the resulting $\mathrm{GWP}_{100}$ comes from the cultivation of grain (economic allocation, Table 3), bioethanol plant operation and construction, raw materials transportation (Fig. 4), bioethanol transportation calculated assuming distribution within a radius of $120 \mathrm{~km}$, ethanol combustion, and the corresponding 
$394 \mathrm{CO}_{2}$ binding to wheat grain (Table 7). The credit from replacing $236000 \mathrm{Mg} \mathrm{y}^{-1}$ of soy meal equivalent is $-171000 \mathrm{Mg} \mathrm{y}^{-1}$. The net $\mathrm{GWP}_{100}$ of $422000 \mathrm{Mg} \mathrm{y}^{-1}$ corresponds to $39.0 \mathrm{~g} \mathrm{MJ}^{-1}$ (Table 9), thus achieving a reduction by 54\%. This $\mathrm{GWP}_{100}$ from overall wheat bioethanol and DDGS system is less than the impact allocated to cradle to bioethanol product utilisation route by economic values in Table 7, due to the account of credit from the replacement of soy meal by DDGS.

Nevertheless, both approaches (39\% based on bioethanol allocation and 54\% based on bioethanol and DDGS co-production and utilisation, respectively) demonstrate that a standalone UK wheat bioethanol subsystem may not meet the EU Renewable Energy Directive constraint on GHG emission reduction by $>60 \%$ by 2020 . Therefore, other alternatives to improve environmental performance of the bioethanol production need to be studied. In case of CPE, the saving is $56 \%$ with respect to the production of gasoline. The following cases make reference to the values from the wheat bioethanol plant as in base case (1). For alternative number (2), the production of $2.95 \mathrm{PJ}^{-1}$ of heat from burning all the DDGS (LHV of $18.2 \mathrm{MJ} \mathrm{kg}^{-1}$, carbon mass content of 45\%) [37] is utilised within the bioethanol plant. The bioethanol plant heat requirement (as steam) from natural gas is completely replaced by the heat from DDGS and $0.95 \mathrm{PJ} \mathrm{y}^{-1}$ of excess heat is produced for the grid. Therefore, the CPE of $2.03 \mathrm{PJ} \mathrm{y}^{-1}$ and $1.36 \mathrm{PJ} \mathrm{y}^{-1}$, respectively, are subtracted from the base case and the net CPE of the system is reduced to $3.20 \mathrm{PJ}^{-1}$. The net bioenergy produced is now of $11.8 \mathrm{PJ} \mathrm{y}^{-1}$ and the overall effect is an increase in the energy ratio to 3.67.

414 This gives savings of $77 \%$ in fossil CPE from the production of bioethanol with respect to the production of gasoline. However, the net $\mathrm{GWP}_{100}\left(\mathrm{as} \mathrm{CO}_{2}\right.$-eq) is increased to $874000 \mathrm{Mg} \mathrm{y}^{-1}$ due to the addition of $487000 \mathrm{Mg} \mathrm{y}^{-1}$ from DDGS combustion, even after the credits from the replacement of $122000 \mathrm{Mg} \mathrm{y}^{-1}$ and excess heat of $83300 \mathrm{Mg} \mathrm{y}^{-1}$ (Table 9). No additional $418 \mathrm{CO}_{2}$ binding is credited since DDGS comes from the processing of wheat grain (and the 
corresponding credit was already accounted in the base case (1)). Also, the electricity is supplied from the grid. As a result, the balance over case (2) indicates higher $\mathrm{GWP}_{100}$ impact of $80.9 \mathrm{~g} \mathrm{MJ}^{-1}$ bioethanol produced yielding a marginal saving by $4 \%$.

An alternative 3, where the DDGS (moisture and ash mass contents of $8 \%$ and $3.9 \%$ respectively) is used as a raw material for the CHP plant and the energy generated is delivered to the bioethanol plant and the excess electricity is exported to grid, is considered. The DDGS conversion process provides $0.78 \mathrm{PJ} \mathrm{y}^{-1}$ of heat and $1.47 \mathrm{PJ} \mathrm{y}^{-1}$ of electricity (Fig. 7). All the electricity requirements $\left(0.12 \mathrm{PJ} \mathrm{y}^{-1}\right)$ by the bioethanol plant are thus completely replaced by the renewable electricity. $39 \%$ of the heat required by the bioethanol plant is also replaced. Thus, the corresponding credits can be subtracted from the impacts of the base case as before. Thus, after using the heat and required electricity within the bioethanol plant, the net bioenergy produced by the bioethanol $\left(10.8 \mathrm{PJ} \mathrm{y}^{-1}\right)$ and DDGS CHP $\left(1.4 \mathrm{PJ} \mathrm{y}^{-1}\right)$ system is 12.2 $\mathrm{PJ} \mathrm{y}^{-1}$. As in case (2), the net $\mathrm{GWP}_{100}$ is increased from that of the base case due to the fact that $\mathrm{CO}_{2}$ emissions are added to the system from the DDGS CHP plant and there is no credit for DDGS replacing soy meal. This system benefits from the production of renewable electricity and can achieve $\mathrm{GWP}_{100}$ savings by $17 \%$ after credits. $93 \%$ of the CPE is replaced by an equivalent amount of bioenergy (bioethanol-DDGS based CHP). allocated $\mathrm{GWP}_{100}$ to straw from the wheat cultivation system must be included into the base case $\mathrm{GWP}_{100}$. Additionally, the $\mathrm{CPE}$ and the $\mathrm{GWP}_{100}$ from the straw-based CHP plant operation and construction and straw transportation should be added. However, the integration of straw-based $\mathrm{CHP}$ with bioethanol plant can take advantage of additional $\mathrm{CO}_{2}$ binding by the straw. Besides, DDGS is sold for animal feed, replacing soy meal and gaining the corresponding credits as in the base case (1). Similarly to case (3), the straw based CHP plant replaces a part of the heat required by the bioethanol plant (37\%) and there is excess 
electricity exported to grid. The resulting net $\mathrm{GWP}_{100}$ reduction is $85 \%$, fulfilling the $\mathrm{EU}$

445 Directive 60\% emission reduction target. By taking all the credits, the CPE requirement by 446 the system reduces by $97 \%$. The net bioenergy is $12.1 \mathrm{PJ} \mathrm{y}^{-1}$ (Table 9) from 172370 ha of 447 grade 3 land use (Table 3) providing land energy yield of $70 \mathrm{GJ} \mathrm{ha}^{-1} \mathrm{y}^{-1}$.

Case 5 was explored by integrating the bioethanol plant with the straw-based CHP plant and DDGS combustion to supply the balance of heat (steam) required by the bioethanol plant. This case is a combination between cases 2 and 4 . The integration is about supplying the entire heat requirement of $2.0 \mathrm{PJ} \mathrm{y}^{-1}$ from the straw $\mathrm{CHP}$ plant $\left(0.74 \mathrm{PJ} \mathrm{y}^{-1}\right)$ and from the DDGS heat $\left(1.26 \mathrm{PJ} \mathrm{y}^{-1}\right)$ that completely replace the fossil-based heat (steam). The electricity requirement and the excess electricity generation are similar as in case $4.126000 \mathrm{Mg} \mathrm{y}^{-1}$ of DDGS are required (assuming energy content as in case 2) to supply the balance of heat. Therefore, the system can still gain credits from $168000 \mathrm{Mg} \mathrm{y}^{-1}$ of DDGS replacing 135000 $\mathrm{Mg} \mathrm{y}^{-1}$ soy meal, thus resulting in $\mathrm{GWP}_{100}$ and CPE savings. The overall GHG emission reduction is $63 \%$ with respect to the use of gasoline. The CPE for the base case (1) is not only replaced by the production of bioenergy, but additionally energy in the form of excess electricity and bioethanol is saved. This system thus also achieves the EU Directive's $60 \%$ GHG emission reduction target. effective way to achieve the EU Directive $\mathrm{GWP}_{100}$ reduction target, while saving fossil CPE. The complete replacement of heat (steam) and electricity by straw CHP and DDGS in 464 alternative 5 is another option in which $\mathrm{GWP}_{100}$ is lower but more fossil CPE can be saved. The incentives for the reduction of $\mathrm{GWP}_{100}$ beyond the target and the capital costs involved in the two integrated systems would finally determine the selection of one of these alternatives. The LCA approach presented took detailed account of $\mathrm{CO}_{2}$ binding by wheat 
plant and the emissions from fermentation and combustion (ethanol, DDGS and/or straw).

469 The saving results found for alternatives 4 and 5 are similar to those reported in [16].

470 Table 9 Summary of overall results on $\mathrm{GWP}_{100}\left(\mathrm{CO}_{2}-\mathrm{eq}\right)$ in $\mathrm{Mg} \mathrm{y}^{-1}, \mathrm{CPE}$ in $\mathrm{PJ} \mathrm{y}^{-1}$ and 471 corresponding savings.

\begin{tabular}{|c|c|c|c|c|c|}
\hline Alternative & (1) & (2) & (3) & (4) & (5) \\
\hline \multicolumn{6}{|c|}{$\mathbf{G W P}_{\mathbf{1 0 0}}$ from different subsystems and combustion } \\
\hline Cultivation & 591000 & 591000 & 591000 & 604000 & 604000 \\
\hline Bioethanol plant & 555000 & 555000 & 555000 & 555000 & 555000 \\
\hline $\mathrm{CO}_{2}$ binding & -1330000 & -1330000 & -1330000 & -1810000 & -1810000 \\
\hline Ethanol combustión & 774000 & 774000 & 774000 & 774000 & 774000 \\
\hline DDGS combustión & - & 487000 & - & - & 208000 \\
\hline CHP plant & - & - & 488000 & 487000 & 487000 \\
\hline Subtotal GWP $\mathbf{P}_{100}$ & 590000 & 1080000 & 1080000 & 610000 & 818000 \\
\hline \multicolumn{6}{|c|}{ CPE and GWP 100 credits } \\
\hline \multicolumn{6}{|c|}{ From DDGS replacing soy meal } \\
\hline $\mathrm{GWP}_{100}$ credit & 171000 & 0 & 0 & 171000 & 98000 \\
\hline CPE credit & 0.98 & 0 & 0 & 0.98 & 0.56 \\
\hline \multicolumn{6}{|c|}{ From fossil based energy replaced } \\
\hline Heat & & 2.95 & 0.78 & 0.74 & 2 \\
\hline $\mathrm{GWP}_{100}$ credit & & 206000 & 48100 & 45100 & 122000 \\
\hline CPE credit & & 3.39 & 0.79 & 0.75 & 2.03 \\
\hline Electricity & & 0 & 1.47 & 1.38 & 1.38 \\
\hline $\mathrm{GWP}_{100}$ & & 0 & 273000 & 256000 & 256000 \\
\hline $\mathrm{CPE}$ & & 0 & 4.73 & 4.44 & 4.44 \\
\hline Net $G_{W P} P_{100}$ after credits & 422000 & 874000 & 760000 & 137000 & 341000 \\
\hline Net CPE after credits & 5.62 & 3.20 & 1.09 & 0.47 & -0.43 \\
\hline \multicolumn{6}{|c|}{ Values from reference fuel (gasoline) } \\
\hline $\mathbf{G W P}_{100}$ & \multicolumn{5}{|c|}{914000} \\
\hline CPE & \multicolumn{5}{|c|}{12.9} \\
\hline \multicolumn{6}{|c|}{ Final results } \\
\hline Net bioenergy & 10.8 & 11.8 & 12.2 & 12.1 & 12.1 \\
\hline$G W P_{100}\left(g_{M J} \mathbf{M J}^{-1}\right)$ & 39.02 & 80.91 & 70.37 & 12.63 & 31.55 \\
\hline $\mathbf{G W P}_{100}$ reduction & $54 \%$ & $4 \%$ & $17 \%$ & $85 \%$ & $63 \%$ \\
\hline $\mathbf{E}_{\text {ratio }}$ & 1.92 & 3.67 & 11.10 & 27.62 & - \\
\hline CPE saving & $56 \%$ & $77 \%$ & $92 \%$ & $97 \%$ & $103 \%$ \\
\hline
\end{tabular}

\section{Conclusions}

A cradle to grave LCA of the UK whole wheat-based bioethanol and straw-based

475 CHP system has been performed considering the various IC including GWP 100 and CPE. It is 
476 demonstrated that the wheat cultivation, wheat bioethanol plant and straw CHP plant, if

477 deployed in an integrated manner, can be more environmentally sustainable than the

478 reference fossil-based system.

A transparent and comprehensive approach that included LCA of the UK wholewheat cultivation, transportation and construction and operation of plants and utilisation of end products has been demonstrated. The analysis showed that the state-of-the-art bioethanol systems may not achieve the EU Directives' minimum GHG emission reduction target of $60 \%$. Therefore, five integrated systems, wherein bioethanol energy requirements were met by lignocellulosic energy, were proposed. Cases 2 and 3, with DDGS used as a source of heat and CHP, respectively, improve the energy use of the system thereby saving CPE, but incur no emission reduction. The other two integration alternatives with bioethanol energy requirements met by straw CHP (alternative 4) and straw CHP and DDGS heat (alternative 5) respectively, achieve the EU Directive's target GHG reductions. The system in alternative 4 offers $\mathrm{GWP}_{100}$ reduction by $85 \%$ and CPE savings by $97 \%$, whilst the system in alternative 5 achieves the EU Directive's target $\mathrm{GWP}_{100}$ reduction (63\%) and CPE saving of more than $100 \%$. The system assessed has also the advantage that no land use change is involved and impact on water is also negligible. A high yield of total bioenergy per ha must be attained implying an efficient use of land, a factor that is important considering that the land is a limiting resource. Concluding from various integration synergies within bioenergy systems and integrated energy system alternatives this study clearly demonstrates an urgent need for greater exploitation of lignocellulosic energy systems into biorefineries.

\section{Acknowledgements}

Mr. Martinez is grateful to the Mexican National Council on Science and Technology (CONACYT) for the financial support during his $\mathrm{PhD}$ studies. 
501 [1] Home Grown Cereals Authority (UK). Statistics from HGCA Knowledge Centre. www.hgca.com/minisite_manager.output/3527/3527/Knowledge\%20Centre/Current\%20Mar ket\%20Outlook/UK\%20wheat\%20balance\%20sheet.mspx?minisiteId=11; [accessed Jul 2011].

505

[2] Nix JS. Farm Management Pocketbook. 36th edition. London: The Andersons Centre, Imperial College London; 2005.

507

[3] Copeland J and Turley D. National and regional supply/demand balance for agricultural straw in Great Britain. Report to the NNFCC November 2008. York (UK): National NonFood Crops Centre; 2008. www.nnfcc.co.uk/metadot/index.pl?id=8331;isa=DBRow;op=show;dbview_id=2539;

$511 \quad$ [accessed Jul 2011].

512 [4] Department of Trade and Industry (UK). Meeting the Energy Challenge (Energy White 513 Paper). London: Department of Trade and Industry; 2007.

514 www.berr.gov.uk/files/file39387.pdf; [accessed Jul 2011].

515 [5] Renewable Fuels Agency (UK). The Renewable Transport Fuel Obligations Order 2007 516 (as amended, version in force on 15 April 2009).

517 www.renewablefuelsagency.gov.uk/sites/renewablefuelsagency.gov.uk/files/_documents/RT 518 FO_Order_as_amended_April_2009.pdf; [accessed Jul 2011].

519 [6] Sadhukhan J, Mustafa MA, Misailidis N, Mateos-Salvador F, Du C, Campbell GM. Value 520 analysis tool for feasibility studies of biorefineries integrated with value added production.

521 Chem Eng Sci 2008;63(2):503-19.

522 [7] The UK Renewable Energy Strategy. Presented to Parliament by the Secretary of State for 523 Energy and Climate Change by command of Her Majesty. London: Crown Copyright; 2009. 
http://www.co2sense.org.uk/uploads/public/Templates/img/TheUKRenewableEnergyStrateg y2009.pdf; [accessed July 2011].

[8] Perry M, Rosillo-Calle F. Recent trends and future opportunities in UK bioenergy:

Maximising biomass penetration in a centralised energy system. Biomass Bioenergy 2008;32(8):688-701.

[9] Directive 2009/28/EC of the European Parliament and of the Council of 23 April on the promotion of the use of energy from renewable sources and amending and subsequently repealing Directives 2001/77/EC and 2003/30/EC. Official J Eur Union 2009. http://eurlex.europa.eu/LexUriServ/LexUriServ.do?uri=OJ:L:2009:140:0016:0062:EN:PDF; [accessed Jul 2011].

[10] Thamsiriroj T, Murphy JD. Can Rape Seed Biodiesel Meet the European Union Sustainability Criteria for Biofuels? Energy Fuels 2010;24(3):1720-30.

[11] Thamsiriroj T, Murphy JD. Is it better to import palm oil from Thailand to produce biodiesel in Ireland than to produce biodiesel from indigenous Irish rape seed? Appl Energy 2009;86(5):595-604.

[12] Murphy JD, Power NM. An argument for using biomethane generated from grass as a biofuel in Ireland. Biomass Bioenergy 2009;33(3):504-12.

[13] Elsayed MA, Matthews R, Mortimer ND (Resources Research Unit, Sheffield Hallam University, Sheffield, UK). Carbon and energy balances for a range of biofuel options. Final report 2003 Mar. Sheffield (UK): Department of Trade and Industry (UK); 2003. 341 p. Report No.: URN 03/086. Contract No.: B/B6/000784/00/00.

[14] Rowe RL, Street NR, Taylor G. Identifying potential environmental impacts of large scale deployment of dedicated bioenergy crops in the UK. Renew Sustain Energy Rev 2009;13(1):271-290. 
[15] Cherubini F, Bird ND, Cowie A, Jungmeier G, Schlamadinger B, Woess-Gallasch S.

549 Energy- and greenhouse gas-based LCA of biofuel and bioenergy systems: Key issues,

550 ranges and recommendations. Resour Conserv Recy 2009;53(8):434-47.

551 [16] Cherubini, F, Ulgiati S. Crop residues as raw materials for biorefinery systems -

552 A LCA case study. Appl Energy 2010;87(1):47-57.

553 [17] Bernesson, S, Nilsson D, Hansson P. A limited LCA comparing large -and small- scale

554 production of ethanol for heavy engines under Swedish conditions. Biomass Bioenergy

$555 \quad 2006 ; 30(1): 46-57$.

556 [18] Goglio P, Owende PMO, A screening LCA of short rotation coppice willow (Salix sp.)

557 feedstock production system for small-scale electricity generation, Biosystems Eng

$558 \quad 2009 ; 103(3): 389-394$.

559 [19] Williams AG, Audsley E, Sandars DL. Determining the environmental burdens and

560 resource use in the production of agricultural and horticultural commodities. Final report

5612006 Aug. Bedford (UK): Cranfield University and DEFRA (UK); 2006. 97 p. DEFRA

562 Research Project No.: IS0205. Supported by Department for Environment, Food and Rural

563 Affairs (UK).

564 [20] Forster P, Ramaswamy V, Artaxo P, Berntsen T, Betts R, Fahey DW, et al. Changes in

565 Atmospheric Constituents and in Radiative Forcing. In: Solomon S, Qin D, Manning M,

566 Chen Z, Marquis M, Averyt KB, et al. (editors). Climate Change 2007: The physical science

567 basis. Contribution of Working Group I to the fourth assessment report of the IPCC.

568 Cambridge (UK): Cambridge University Press, 2007.

569 [21] Azapagic A, Perdan S, Clift R. Sustainable development in practice: Case studies for

570 engineers and scientists. West Sussex (UK): John Wiley \& Sons Ltd; 2004. Appendix, Life

571 cycle thinking and life cycle assessment (LCA); p. 426-37. 
572 [22] Eggleston HS, Buendia L, Miwa K, Ngara T, Tanabe K (editors). IPCC Guidelines for

573 National Greenhouse Gas Inventories, prepared by the National Greenhouse Gas Inventories

574 Programme of the IPCC. Hayama (Japan): IGES, 2006.

575 [23] Institute of Environmental Sciences (CML), Leiden University. Abiotic depletion

576 potentials (ADPs). Leiden (Netherlands): Leiden University, 2002.

577 http://cml.leiden.edu/research/industrialecology/researchprojects/finished/abiotic-depletion-

$578 \quad$ lcia.html; [accessed Jul 2011].

579 [24] Küsters J. Energy and CO2 balance of bioenergy plants and of various forms of bio

580 energy. Paper presented at: International Symposium on Nutrient Management and Nutrient

581 Demand of Energy Plants; 2009 July 07-08; Budapest, Hungary. Available at:

582 www.ipipotash.org; [accessed Jul 2011].

583

[25] International Iron \& Steel Institute (IISI). Worldwide LCI study for steel products. The

International Stainless Steel Forum (ISSF), 1999/2000. www.worldstainless.org; [accessed Jul 2011].

[26] Wu X, Zhang Z., Chen Y. Study of the environmental impacts based on the "green tax"

- applied to several types of building materials. Build Environ 2005;40(2):227-37.

[27] Plastics Europe (Association of Plastics Manufacturers). Eco-profiles of the European

Plastics Industry. www.lca.plasticseurope.org/index.htm; [accessed Jul 2011].

[28] Nielsen PH, Oxenboll KM, Wenzel H. Cradle-to-gate environmental assessment of

enzyme products produced industrially in Denmark by Novozymes A/S. Int J LCA

$592 \quad 2006 ; 12(6): 432-38$.

593

[29] European Union Commission, European IPCC Bureau. Reference document on Best other industry (LVIC-S). Final Version Aug 2007. http://eippcb.jrc.es; [accessed Jul 2011] 
596 [30] Sadhukhan J, Ng KS, Shah N, Simons HJ. Heat integration strategy for economic

597 production of combined heat and power from biomass waste. Energy Fuels

$598 \quad 2009 ; 23(10): 5106-20$.

599 [31] Kwiatkowski JR, McAloon AJ, Taylor F, Johnston DB. Modeling the process and costs 600 of fuel ethanol production by the corn dry-grind process. Ind Crop Prod 2005;23(3):288-96.

601 [32] American Petroleum Institute. API 650 Welded Steel Tanks for oil Storage. 8th. Edition.

602 Washington D.C., 1988.

603 [33] Wooley R, Ruth M, Sheehan J, Ibsen K, Majdeski H, Galvez A. Lignocellulosic biomass 604 to ethanol process design and economics utilizing co-current dilute acid prehydrolysis and 605 enzymatic hydrolysis current and futuristic scenarios. Golden, Colorado (US): National 606 Renewable Energy Laboratory; 1999. 132 p. Report No.: NREL/TP-580-26157. Contract No. 607 DE-AC36-98-GO10337. Supported by Department of Energy (US).

608 [34] Kim S, Dale BE. Allocation Procedure in Ethanol Production System from Corn 609 Grain I. System Expansion. Int J LCA 2002;7(4):237-43.

610 [35] Dalgaard R, Schmidt J, Halberg N, Christensen P, Thrane M, Pengue WA. LCA of 611 soybean meal. Int J LCA 2008;13(3):240-54.

612 [36] Bridgwater AV. The technical and economic feasibility of biomass gasification for 613 power generation. Fuel 1995;74(5):631-53.

614 [37] Sebesta Blomberg \& Associates, Inc. Feasibility of Producing Electricity and Heat 615 Utilizing Steam Turbines and Spark Ignited Engine Generators at Generation II's Corn 616 Ethanol Plant. Final report 18 Sep 2003. Minneapolis (US): Xcel Energy, Inc.; 2003. 38 p. 